\title{
Identification of Tundra Land Cover near Teshekpuk Lake, Alaska Using SPOT Satellite Data
}

\author{
CARL J. MARKON ${ }^{1}$ and DIRK V. DERKSEN ${ }^{2}$
}

(Received 16 August 1993; accepted in revised form 21 March 1994)

\begin{abstract}
Tundra vegetation in the Teshekpuk Lake area of the Alaskan Arctic Coastal Plain was mapped to assess distribution and abundance of waterfowl habitats. Three SPOT satellite scenes were acquired and registered to a $20 \mathrm{~m}$ Universal Transverse Mercator grid. Two clustering techniques were used to develop statistical parameters by which the SPOT data were spectrally classified. A maximum likelihood algorithm that correlated spectral classes with land cover types was applied to the SPOT data. Field data were used to assist in spectral class labeling and vegetation descriptions. Twelve cover classes were mapped. The most common type was moist sedge meadow tundra (13.5\%); the least common was moss/peat shoreline (0.2\%). The moss/peat shoreline type, important to moulting geese and other waterfowl, was spectrally identified using supervised clustering techniques. All other land cover types were identified using unsupervised clustering techniques. Cover classes were described, and a tundra landscape profile produced.
\end{abstract}

Key words: tundra land cover mapping, SPOT satellite data, Teshekpuk Lake, Alaska

RÉSUMÉ. On a dressé une carte de la végétation de toundra dans la région du lac Teshekpuk de la plaine côtière arctique de l'Alaska afin d'évaluer la distribution et l'abondance de l'habitat de la sauvagine. On s'est procuré trois scènes prises par le satellite SPOT, qu'on a alignées sur un quadrillage de $20 \mathrm{~m}$ de la projection transverse universelle de Mercator. On a utilisé deux techniques d'agrégation pour élaborer des paramètres statistiques grâce auxquels on a classé en fonction du spectre les données provenant du SPOT. On a appliqué aux données du SPOT un algorithme de vraisemblance maximale corrélant les classes spectrales avec les types de couvert végétal. On a utilisé des données de terrain pour aider à nommer les classes spectrales et à décrire la végétation. On a cartographié 12 classes de couvert végétal, le plus commun étant la toundra de prairie à laîches humide (13,5 p. cent), et le moins abondant étant le littoral de mousse/tourbe ( $0,2 \mathrm{p}$. cent). On s'est servi de techniques d'agrégation dirigées pour identifier en fonction du spectre le type de mousse/tourbe, important pour les oies en période de mue et autre sauvagine. Tous les autres types de couvert végétal ont été identifiés à l'aide de techniques d'agrégation non dirigées. On a décrit les classes de couvert et établi un profil de paysage de toundra.

Mots clés: cartographie du couvert végétal de la toundra, données provenant du satellite SPOT, lac Teshekpuk, Alaska

Traduit pour la revue Arctic par Nésida Loyer.

\section{INTRODUCTION}

The Arctic Coastal Plain of Alaska provides important summer habitats for a diversity of migratory birds (Pitelka, 1974; Bergman et al., 1977). The Teshekpuk Lake area, located about $160 \mathrm{~km}$ east of Point Barrow (Fig. 1), is important because of its value to breeding shorebirds, waterfowl, and passerines (Derksen et al., 1981). The area is also an internationally important moulting area for Pacific black brant (Brantaberniclanigricans) and other geese (Derksen et al., 1979; 1982).

Rapid westward expansion of petroleum development from Prudhoe Bay necessitated a precise inventory of land cover for management of migratory birds and planning industrial development in the Teshekpuk Lake area (Penfold and Buoy, 1986). Previous vegetation maps (Küchler, 1966; Selkregg, 1975; Morrissey and Ennis, 1981) did not provide sufficient resolution for identification of specific communities used by migratory birds. In 1987 we initiated a cooperative effort to produce a land cover map of the Teshekpuk Lake area.
Although other satellite data from Landsat, the advanced very high resolution radiometer (AVHRR), and historical aerial photography are available for the Teshekpuk Lake area, Système Pour l'Observation de la Terre (SPOT) multispectral scanner (MSS) data were used because 1) the data were relatively recent (1986) and were 99\% cloud-free, 2) 20 $\mathrm{m}$ resolution could detect small wetland communities, and 3) processing could be accomplished in a geo-referenced digital data base. A geo-referenced data base allows area summaries of each individual attribute on a project-wide or site-specific basis and the overlay of other geo-referenced data.

\section{STUDY AREA}

The Teshekpuk Lake area is centrally located on the Arctic Coastal Plain of Alaska and comprises about 210000 ha (Fig. 1). The project area is bordered on the north by the Beaufort Sea, on the east by Harrison Bay, on the west by the Ikpikpuk River, and to the south by Teshekpuk Lake and the Kogru River. The most

\footnotetext{
${ }^{1}$ HUGHES STX Corporation, EROS Alaska Field Office, 4230 University Drive, Room 230, Anchorage, Alaska 99508-4664, U.S.A.

${ }^{2}$ Alaska Fish and Wildlife Research Center, National Biological Survey, 1011 East Tudor Road, Anchorage, Alaska 99503, U.S.A.

(C) The Arctic Institute of North America
} 
prominent characteristic of the Teshekpuk Lake area is the large, directionally-oriented thaw lakes and second-or later-generation wetlands (Black and Barksdale, 1949). Wetlands comprise approximately $30 \%$ of the area and vary in size from flooded tundra depressions to thaw lakes up to $14.5 \mathrm{~km}$ in length (Derksen et al., 1992). The project area lies in the Arctic Coastal Plain Province (Wahrhaftig, 1965) and is characterized by deep $(182+m)$ continuous permafrost, sedge and dwarf shrub tundra vegetation, and ice-wedge polygons (Spetzman, 1959; Wahrhaftig, 1965; Sellmann et al., 1972; Brown and Sellmann, 1973; Selkregg, 1975). Beach deposits and marine sands lie along the northern shore of TeshekpukLake. Marine siltcomprises the remaining portion north and northeast to Cape Halkett (Williams et al., 1977). Soils in the area are generally Histic Pergelic Cryaquepts and Pergelic Cryofibrists, indicating cold (usually less than $0^{\circ} \mathrm{C}$ ) wet soils with surface horizons high in organic matter (Rieger et al., 1979). The growing period for this region generally occurs from 1 June to 30 August, as determined by time series AVHRR data (Loveland et al., 1991).

\section{METHODS}

\section{Data Acquisition and Preprocessing}

SPOT MSS data for the subject area were selected from three suitable scenes; one dated 6 July 1986, and two dated 8 July 1986 . The 8 July satellite scenes were assembled in a mosaic to form one data set. These data provided nearly complete coverage of the Teshekpuk Lake area and full coverage of the important large lake regime in the northern portion of the project area. A digital data base approach was used to produce the land cover classification for the Teshekpuk Lake area (Fleming, 1988; Markon, 1992).

Geo-referencing of the satellite data was accomplished using image registration techniques developed by the U. S. Geological Survey (Ailts et al., 1990) to a Universal Transverse Mercator (UTM) projection in zone 5 at a $20 \mathrm{~m} \times 20 \mathrm{~m}$ pixel size. Control points were selected from United States Geological Survey (USGS) 1:63 360-scale topographic maps. Care was taken to avoid areas that had changed since the 1955 topographic maps were produced (Markon, 1989).

\section{Spectral Statistics and Preliminary Classification}

Unsupervised and supervised image classification techniques (Swain and Davis, 1978) formapping arctic vegetation (Ferguson, 1991; Pearce, 1991) were used to develop spectral statistics for each data set. Because the data sets were acquired on different dates, individual spectral statistics were developed for each. The unsupervised classification began by extracting six training blocks (Fleming, 1988), each approximately $256 \times 256$ pixels $(5.12 \mathrm{~km} \times 5.12 \mathrm{~km})$. The training sites were then grouped, providing an efficient means of combining the spectral variability of the data into a smaller set. Spectral class statistic development and image classification for each scene followed Fleming (1988) and Talbot and Markon $(1986,1988)$. A preliminary label of the land cover type that each spectral class likely represented was then made based on knowledge of the area and field work conducted in 1988. Some land cover types were not represented by the spectral classes produced during the unsupervised classification. Therefore, a supervised approach was used (Swain and Davis, 1978). Image data from areas representative of the missing land cover types were extracted and new spectral statistics(Fleming, 1988) generated. These new spectral statistics were pooled with the original statistical file, analyzed, and again applied to the training sites using a maximum-likelihood classifier (Swain and Davis, 1978). Upon analysis of the data, the new spectral classes were found to be spectrally separable from the other classes. Final spectral statistics were applied to the entire data set using the same maximum-likelihood classifier to produce the land cover classification of the area. A total of 42 spectral classes were produced for the $6 \mathrm{July} 1986$ data set and 56 spectral classes for the 8 July 1988 data set. Each spectral class was assigned to an individual land covertype using aerial photography, personal knowledge of the area, and field data. Spectral classes that appeared to represent more than one cover type or were of doubtful identity were documented and given an "unknown" class identifier (i.e., unknown \#1). Representative sites of all assigned land cover types were examined in the field.

\section{Field Data Collection and Spectral Class Labeling}

Field work was conducted during the last two weeks of July in 1988, 1989, and 1991. A total of 141 data collection sites, located in seven different areas within the Teshekpuk Lake area, were visited on the ground (Fig. 1). Accessibility in the study area was limited and sites were visited by foot or boat. Selection of 1988 field sites was based on preliminary land cover maps. Following each field season, newly acquired information was used to relabel the spectral classes in question and to make a cursory check of the map for accuracy. When selecting a site, the draft map was examined for large, homogeneous polygons of each land cover type. At least three representative samples of each land cover type were visited and the approximate centre located and marked. Types incorrectly classified were selected more often. Site descriptions and notes comparing the preliminary classification to what was actually on the ground then were obtained. Dominant life form (Viereck and Dyrness, 1980), plantspecies, cover and stratum(Mueller-Dombois andEllenberg, 1974), and site moisture were also described. Moisture conditions were estimated subjectively as: 1) dry to touch, 2) moist to touch, 3 ) wet, forming pools when compressed, and 4) flooded.

The field data were used to develop identifying nomenclature and descriptions for each land cover type. Nomenclature for vascular plants followed Hulten (1968) except for willows, which are after Argus (1973) and Viereck and Little (1972). A 35 $\mathrm{mm}$ photo of each site was taken for documentary purposes. Plant species were deposited at the herbarium of the University of Alaska, Anchorage. Plant community and topographic sequences were diagramed at 19 different sites to record plant/ landform relation across a 20 to $200 \mathrm{~m}$ traverse.

After finalizing the nomenclature and type descriptions, each spectral class was assigned to one of 12 final cover types. The 


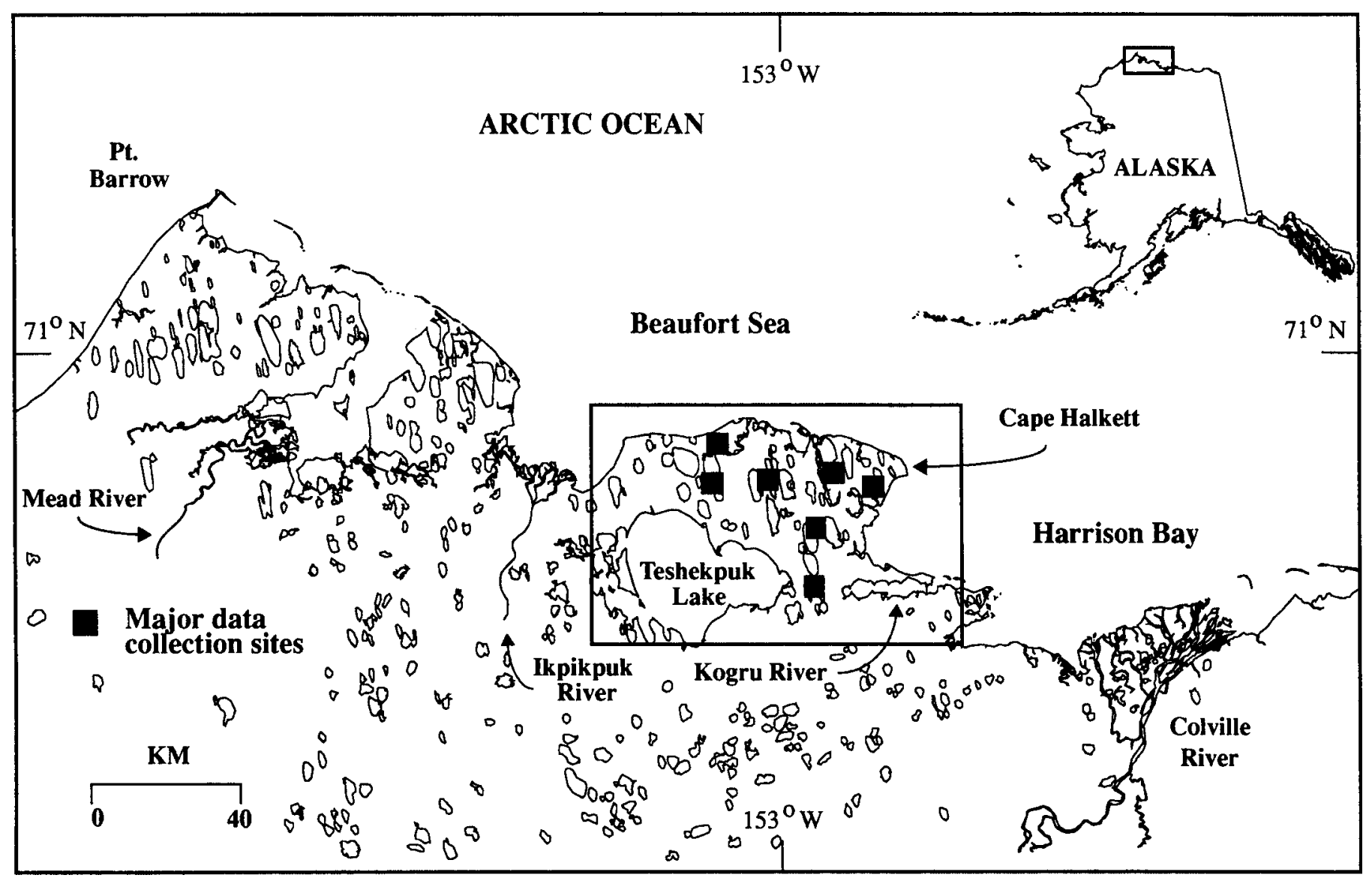

FIG. 1. Teshekpuk Lake project area (inset) with major ground data collection sites indicated.

two classified SPOT scenes were then merged to form one data set. We examined adjacent scenes to verify that habitat types were contiguous.

\section{RESULTS}

Twelve land cover classes wereidentified from digital analysis of the SPOT data. The primary characteristics that allowed separation of cover classes were moisture content, species composition, and vegetation structure. The final map is shown in Figure 2. Area estimates for each class are given in Table 1. Descriptions of each map class follow. Dominant plant species are listed in order of decreasing importance.

Clear Water: Clear water was identified as fresh or saline with little or no particulate matter. Those areas identified as clear water are normally deep (greater than $1 \mathrm{~m}$ ) with little or no vegetation except along the margins, where Arctophila fulva or Carex aquatilis may be present.

Turbid Water: Water that contains large amounts of particulate matter or is less than $1 \mathrm{~m}$ deep.

Flooded Tundra: Normally associated with lake or pond shorelines or small flooded depressions such as low centre polygons that retain water throughout the summer (Fig. 3). Dominant species may include Arctophila fulva, Eriophorum angustifolium, or Carex aquatilis, growing in water depths greater than $10 \mathrm{~cm}$.

Wet Sedge Meadow Tundra: Commonly found in areas with less than $10 \mathrm{~cm}$ deep standing water or in areas of supersaturated soils (Fig. 4; i.e., forming pools when compressed). Carex aquatilis is normally the dominant species, although Eriophorum angustifolium and E. scheuchzeri may comprise up to $25 \%$ of the cover. Other common plants include Ranunculus pallasii, Saxifraga cernua, and Pedicularis sudetica.

Moist Sedge Meadow Tundra: Characterized by moist tundra without ponded water or super-saturated soils. Carex aquatilis, Eriophorum angustifolium, E. russeolum or E. scheuchzeri are the dominant plants (Fig. 5). This type is commonly found in low centre polygons and in drained lake or pond basins. These areas may be flooded during spring melt but are usually moist by July. Moss (Sphagnum spp.) is common in the understory.

In polygonal areas, ridges normally are dominated by Carex aquatilis and may contain mosses, Petasites frigidus, and species of the genera Ranunculus, Saxifraga, Luzula, $P o a$, and Salix.

Halophytic Sedge-Grass Meadow Tundra: Normally found in low areas close to the coast that are periodically exposed to sea spray, which may produce a more saline environment. Vegetation in this class is generally represented by two types: Carex/Puccinellia and Carex aquatilis (Fig. 5). 

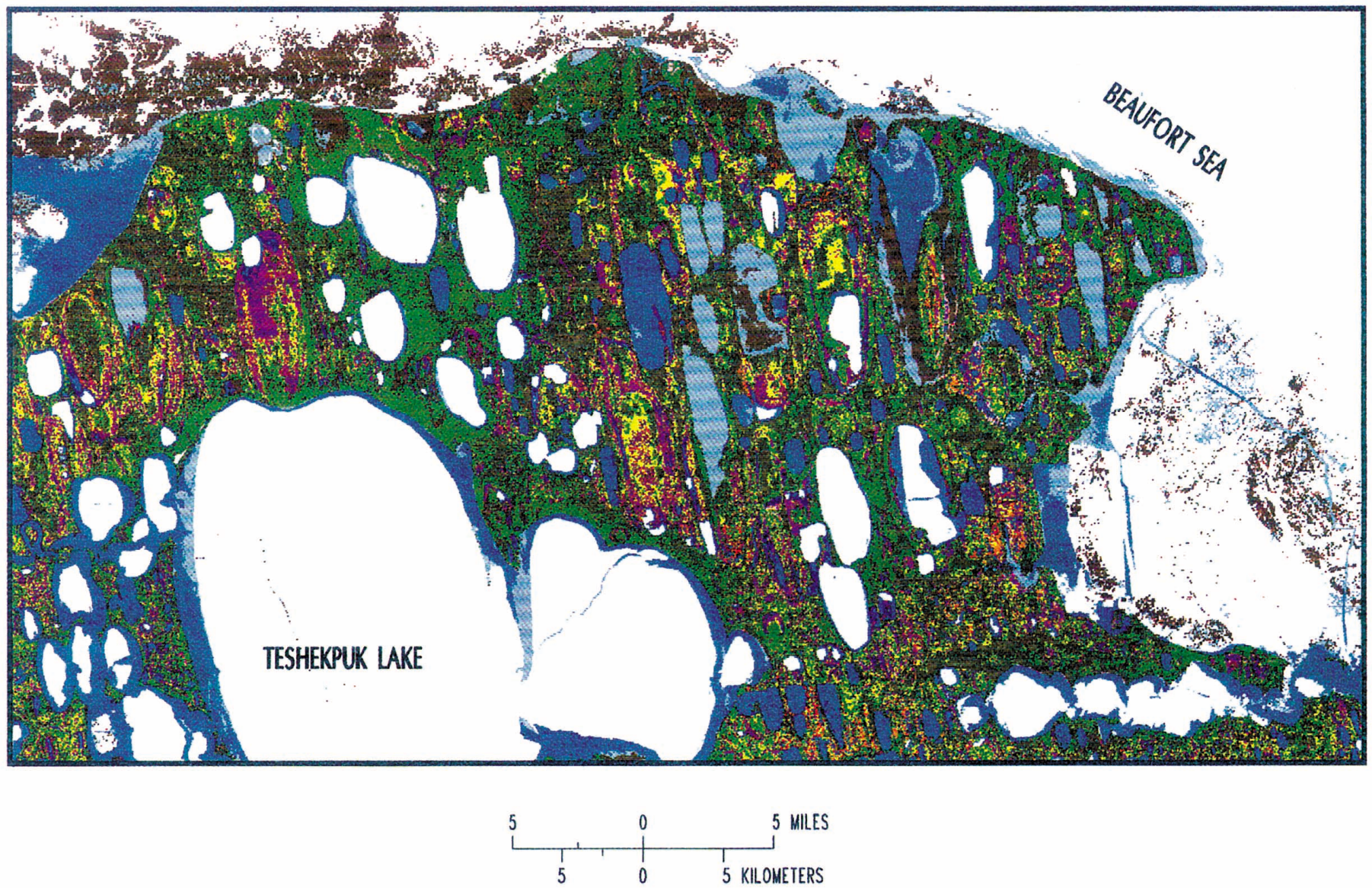

\begin{tabular}{|c|c|c|c|c|}
\hline CLEAR WATER & $\square$ WET SEDGE MEADOW TUNDRA & MOIST GRASS-SEDGE MEADOW TUNDRA & $\square$ & SPARSELY VEGETATED TUNDRA \\
\hline O TURBID WATER & MOIST SEDGE MEADOW TUNDRA & DWAPF SHRUB GRAMINOID TUNDRA & 畻 & UNVEGETATED TUNDRA \\
\hline FLOODED TUNDRA & $\begin{array}{l}\text { HALOPHYTIC SEDGE-GRASS MEADOW } \\
\text { TUNDRA }\end{array}$ & MOSS/PEAT SHORELINE & $\square$ & ICE \\
\hline
\end{tabular}

FIG. 2. SPOT-derived land cover classification of the Teshekpuk Lake special area (original scale 1:125 000).

The Carex/Puccinellia type consists primarily of two small graminoids, Carex subspathacea and Puccinellia phryganodes. This subtype varies from completely vegetated to a patchwork of mud and/or dead vegetation with small vegetated areas. It is often associated with old lake basins that are, or have at one time been, breached by ocean water. Two forbs, Stellaria humifusa and Cochlearia officinalis, are common in areas near the coast.

The Carex aquatilis type is more uniform in total plant cover and is usually dominated by Carex aquatilis. It may, however, have species from the Carex/Puccinellia subtype associated with it. The Carex aquatilis subtype is very similar to the Moist Sedge Meadow Tundra described above and is in some instances floristically equivalent. It is included here because the spectral classes that represented the Carex / Puccinellia type, a true halophytic community, also include the Carex aquatilis type, a fresh water community.

Moist Grass-Sedge Meadow Tundra: This type is dominated by grasses that may account for up to $75 \%$ of the upland cover and is found on moist to dry sites. Two of the most common species found include Arctagrostis latifolia and Poa arctica; the common sedge is Carex aquatilis (Fig. 5). Other species often present include Alopecurus alpinus, Hierochloe alpina, Eriophorum russeolum, Luzula confusa, and species of the genera Saxifraga, Salix, and Sphagnum.

Dwarf Shrub Graminoid Tundra: Occurs on ridges with good drainage or along high lake shorelines (Fig. 6). The relatively dry sites are the most species rich. Major taxa 
TABLE 1. Area estimates by land cover class from the Teshekpuk Lake mapping project.

\begin{tabular}{lrc}
\hline \hline Class Name & Area (ha) & Percent \\
\hline Clear Water & 40393 & 9.9 \\
Turbid Water & 23304 & 5.7 \\
Flooded Tundra & 17254 & 4.2 \\
Wet Sedge Meadow Tundra & 37667 & 9.3 \\
Moist Sedge Meadow Tundra & 54717 & 13.5 \\
Halophytic Sedge-Grass Meadow Tundra & 1868 & 0.5 \\
Moist Grass-Sedge Meadow Tundra & 964 & 0.2 \\
Dwarf Shrub Graminoid Tundra & 23037 & 5.7 \\
Moss/Peat Shoreline & 819 & 0.2 \\
Sparsely Vegetated Tundra & 3044 & 0.7 \\
Unvegetated Tundra & 7459 & 1.8 \\
Ice & 195938 & 48.3 \\
TOTAL & 406464 & 100.0 \\
\hline \hline
\end{tabular}

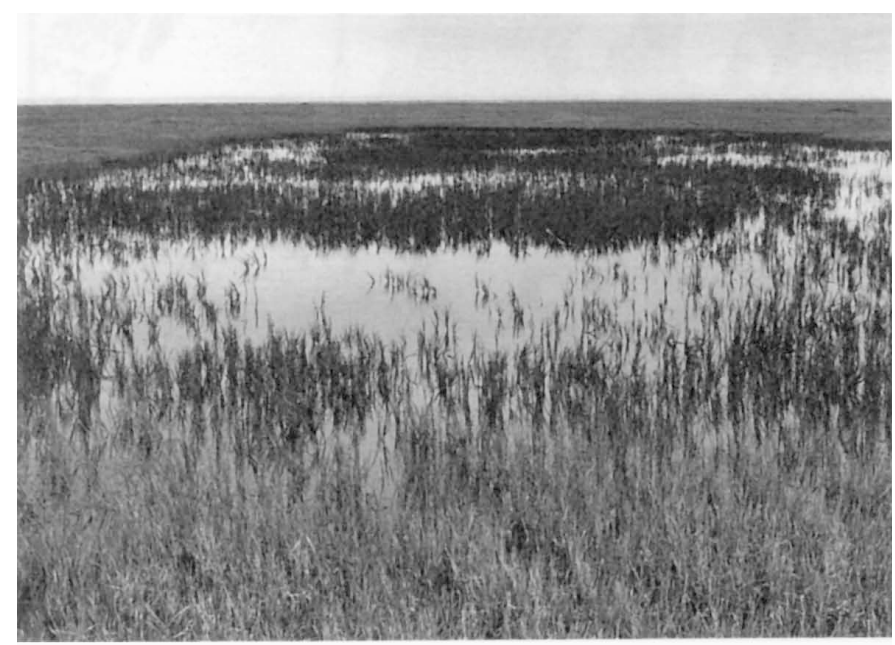

FIG. 3. Flooded tundra with Carex aquatilis at the pond margin and Arctophila fulva in the deeper portion of the basin.

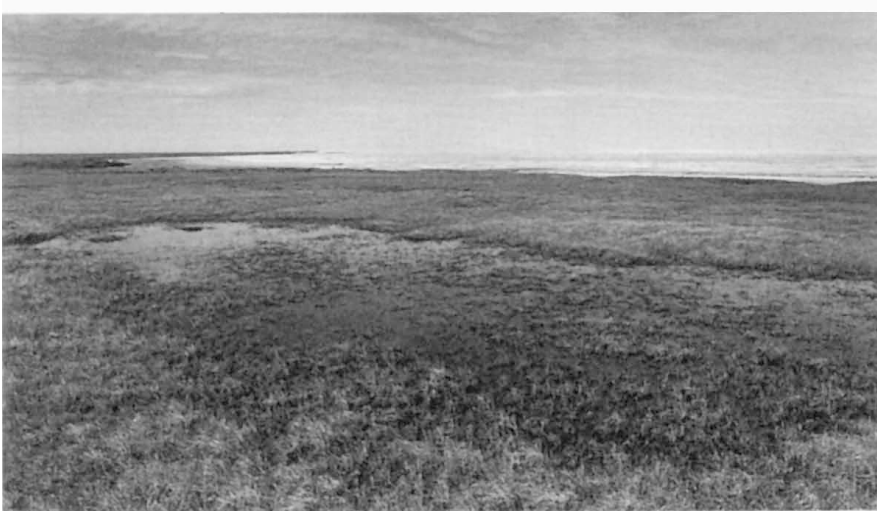

FIG. 4. Wet sedge meadow tundra dominated by Carex aquatilis. Shallow water may evaporate by mid-July.

include: Salix arctica, S. reticulata, S. polaris, Cassiope tetragona, Vaccinium vitis-idaea, Drays drummondii, Rubus chamaemorus, Eriophorum scheuchzeri, E. vaginatum, and Carex aquatilis.

On some sites, this type may contain much grass cover such as Arctagrostis latifolia or Deschampsia caespitosa.
Other plants present include Hierochloe alpina, Luzula multiflora, Petasites frigidus, Pedicularis sudetica, Senecio atropurpureus, Valeriana capitata, and species of the genera Poa, Draba, Papaver, Stellaria, and Saxifraga. Sites in transition between dwarf shrub and graminoid-dominated communities were often spectrally similar to the moist grasssedge meadow tundra type.

Moss/Peat Shoreline: Moss/peat shoreline occurs primarily along low relief shorelines of second generation (Black and Barksdale, 1949) lakes (Fig. 7). It is dominated by mosses, including Sphagnum squarrosum, Drepanocladus lycopodioides, D. revolvens, Campylium arcticum, Aulacomnium turgidum, A. palustre, and Calliergon sarmentosum. As moss/peat grades into a sedge type (Fig. 8), graminoids such as Carex aquatilis may increase in cover to form an intermediate zone. Because this zone is relatively narrow however, the land cover map may show the site as moss.

Sparsely Vegetated Tundra: This class occurs primarily along the coast in areas where storm tides greatly affect the tundra. It also occurs inland in recently drained lake or pond basins that are being recolonized with vegetation. Although vegetation is highly variable, a few of the more common plants include: Senecio congestus, Arctophila fulva, Carex subspathacea, Stellaria humifusa, Cochlearia officinalis, and mosses. Vegetation cover is normally greater than $5 \%$ but less than $20 \%$.

Unvegetated Tundra: Unvegetated tundra was found throughout the study area, especially along ocean and lake shorelines. It also occurred as dirt on offshore ice. Vegetation cover occurring in this type is normally less than $5 \%$. Species composition is similar to sparsely vegetated tundra.

Ice: This is a seasonally variable class. Ice on lakes and larger ponds may last well into late July, with some basins such as Teshekpuk Lake rarely completely ice-free.

\section{Map Assessment}

A detailed accuracy assessment (Hord and Brooner, 1976; van Generen and Lock, 1977; Hay, 1979; Story and Congalton, 1986; Congalton, 1991) was not obtained for the Teshekpuk Lake study area map. However, during the three field excursions, data were collected in areas where the map was weak and corrections made. Confusion between land cover types on the map involved flooded tundra, moist sedge meadow tundra, moss/peat shoreline, dwarf shrub graminoid tundra and unvegetated tundra. The flooded tundra type as mapped was sometimes found as unvegetated tundra. In several areas, sites that were observed as flooded during visits in 1978 were well-drained in 1988. The misclassification of flooded tundra may be due to the drainage of sites from the time the SPOT imagery was acquired and the first field season in 1988. The moist sedge meadow tundra and the dwarf shrub graminoid tundra types appeared to be the most problematic. When checked on the ground these two types sometimes were confused with each other. In other places they were confused with wet sedge meadow tundra. In most cases this misrepresentation occurred in wide-rimmed, low centre 


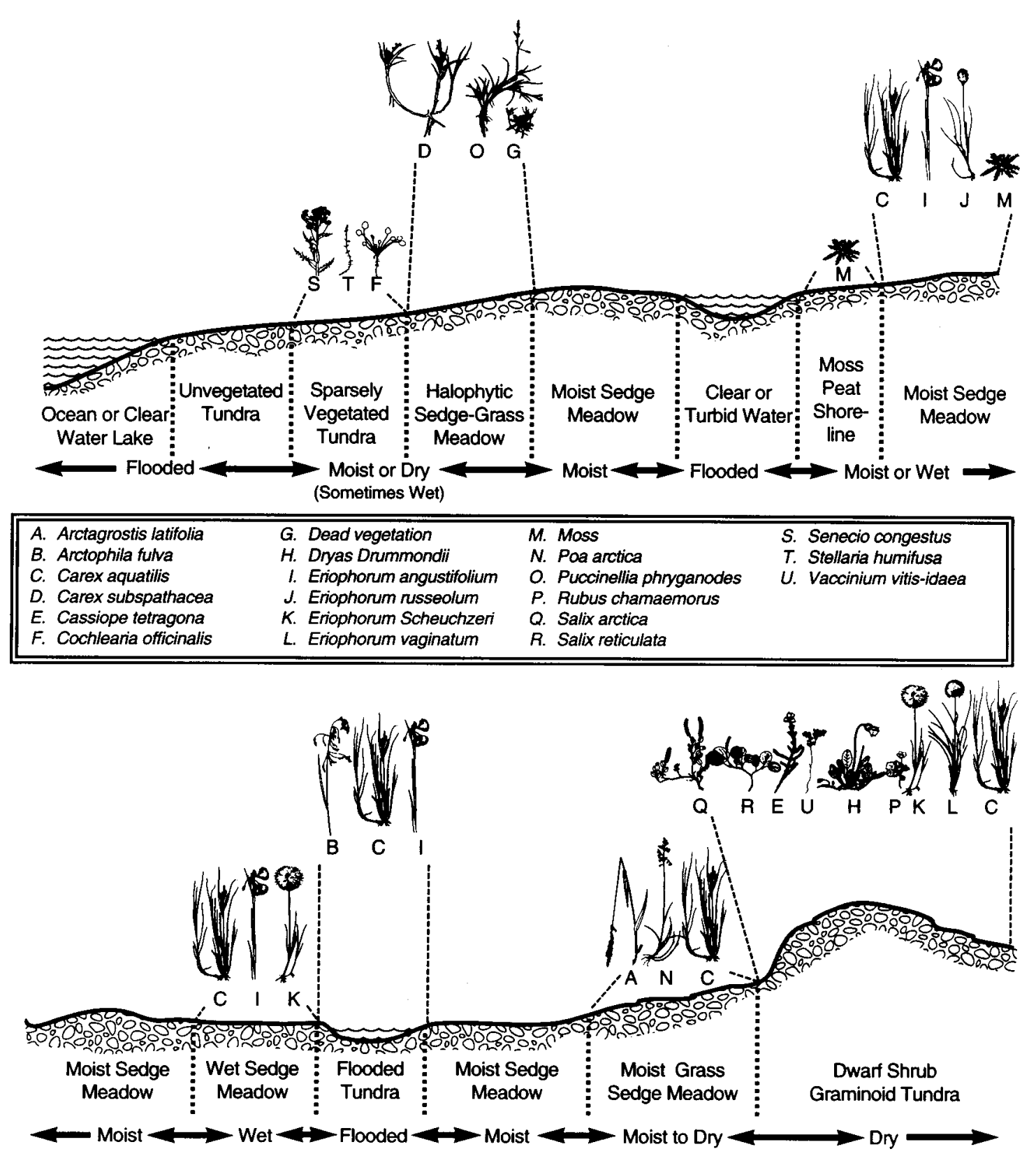

FIG. 5. Landscape profile showing the relation of plant communities to local topography and moisture.

polygon areas, the centres containing sedges in wet to flooded conditions and rims dominated by shrubs.

The moss/peat shoreline type was found to be accurate when located adjacent to pond and lake shorelines. However, in other areas this type was often confused with wet sedge meadow tundra, moist sedge meadow tundra or flooded tundra. On two occasions, moss/peat shoreline type indicated on the map was found to be dwarf shrub graminoid tundra.

\section{Landscape Profile}

The relation of the 12 classes to local topography is shown in Figure 5. Shorelines of larger water bodies or recently drained lake basins (circa 1986) may show a zone of unvegetated to sparsely vegetated tundra (Weller and Derksen, 1979). These areas are normally dry or moist depending on the horizontal and vertical distance from water. If these sites were flooded at the time of image acquisition, they may have been classified as shallow water. The halophytic sedge-grass type usually occurs in low relief areas along the coast or sometimes inland, depending on the effects of storm surges. This type may occur on sites with similar moisture as the unvegetated to sparsely vegetated class; however, it rarely occurs on wet sites. Moist sedge meadow tundra occurs farther from the coast, often ending at shoreline boundaries. This type is normally on moist sites and represents the intermediate zone between dry and wet to flooded conditions. A moss/peat shoreline is commonly associated with larger 
lakes but also may be found on low relief shorelines in small lake or pond complexes. When moss and peat occur in poorly drained conditions, they can hold large amounts of water that create moist to wet conditions. When elevated 20 to $30 \mathrm{~cm}$ above poorly drained areas, this type can dry out and support lichens and vascular plants.

Wet sedge meadows and flooded tundra are found throughout the area, often occurring in low centre polygons and adjacent to small ponds. These classes occur in wet to flooded conditions, often with one merging gradually into the other. The moist grass-sedge meadow type was mapped only on the western half of the study area and occurred on elevated areas between large lakes. The dwarf shrub graminoid tundra type is found on well drained, dry upland sites commonly associated with the $7.5 \mathrm{~m}$ contour, and raised peat mounds associated with high centre polygons. This type also is commonly associated with shorelines of the larger lakes and old lake basin rims.

\section{DISCUSSION}

The SPOT-derived land cover classification of the Teshekpuk Lake area is the second intermediate-scale map produced for the region and shows more recent and detailed vegetation cover than the Morrissey and Ennis (1981) map. Of particular importance was the identification of narrow lakeshore vegetation zones (i.e. moss/peat shorelines) and small wetlands and water bodies that were not identifiable on the resampled $50 \mathrm{~m}$ Landsat data. The land cover types from our study and Morrissey and Ennis (1981) were grouped into six general types for comparison. The general types included water/ice, wet sedge meadow, moist sedge meadow, dwarf shrub tundra, moss/peat shoreline, and unvegetated terrain. The Morrissey and Ennis map included more dwarf shrub tundra and unvegetated areas than the map produced by this study. The SPOT-derived map includes more water/ice, wet sedge meadow, and moss/peat shoreline. The $20 \mathrm{~m}$ spatial

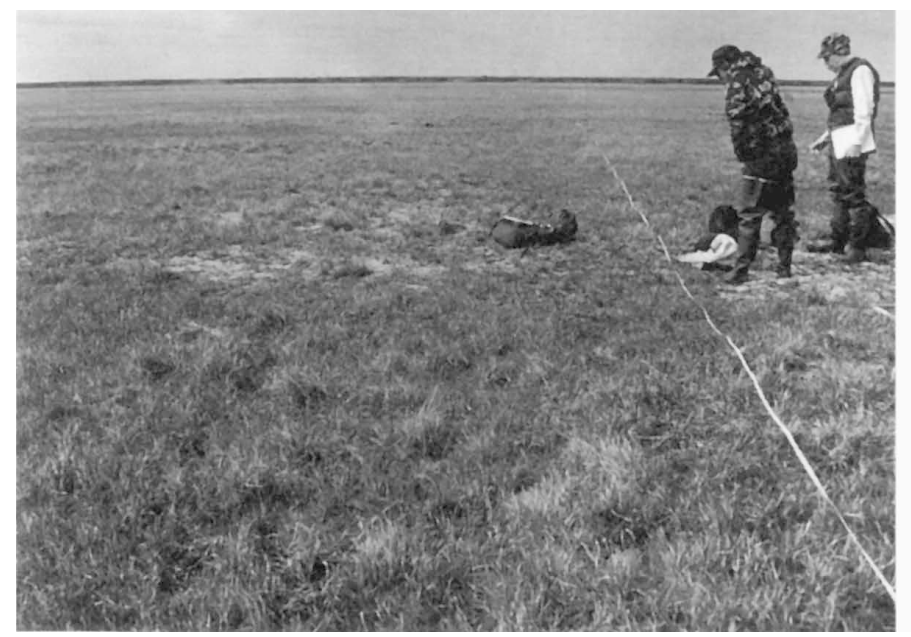

FIG. 6. Dwarf shrub graminoid tundra characterized by willows, grasses, and sedges. resolution SPOT sensor allowed identification of smaller wetlands and the unique moss/peat shoreline, which was not detectable on the Landsat data resampled to $50 \mathrm{~m}$ resolution. The greater amount of dwarf shrub and unvegetated cover types recorded by Morrissey and Ennis (1981) may have been due to the spectral characteristics of dwarf shrub and unvegetated land cover as recorded by the Landsat sensor and the $50 \mathrm{~m}$ pixel size. The dwarf shrub ground cover may record a "greener" response than the surrounding sedge-dominated sites, which retain standing, multi-year dead leafy material. Unvegetated sites have a "brighter" spectral reflectance than the surrounding areas and may contaminate the spectral response of nearby vegetation recorded by the satellite sensor (Dana, 1982).

Whether a detailed accuracy assessment or a less rigorous field checking procedure, as described above, is available, we recommend caution when the data are ultimately used. Often there is a delay of one to ten years between imagery acquisition and analysis and production of a final map. Information gathered during a field season and later during an accuracy assessment give only the conditions at the time of data collection. These data are not always indicative of conditions at the time of satellite passover. This is especially a problem in Alaska where new satellite imagery is seldom acquired. Imagery from the 1980s, and in some cases the 1970s, is still being used to provide land cover classification in previously unmapped areas.

Local weather is an important variable that may affect how ground features will be mapped. If rainfall has occurred shortly before data acquisition, the amount of wetlands recorded may increase. Conversely, if there is a cold period before data acquisition, plant green-up may be delayed and cause the sensor to record data as upland or unvegetated depending on the amount of dead vegetation present. Because these events cannot be controlled, the multi-year field work helped to determine what was "normal" for the area. Weather records and field observations did not show any unusual local weather conditions during the period of data acquisition.

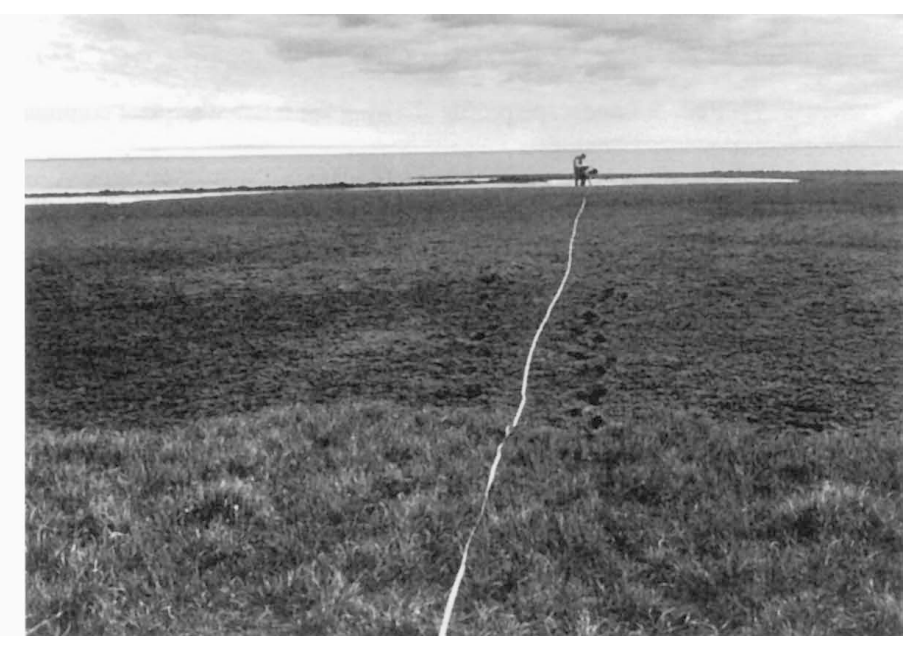

FIG. 8. Lake shoreline showing a transition between a moss/peat zone (background) and moist sedge meadow tundra (foreground). The moss/peat shoreline provides important forage plants for moulting geese. 
Plant-topography sequences in the Teshekpuk Lake area are similar to those recorded elsewere on the Arctic Coastal Plain (Brown and Sellmann, 1973; Webber and Walker, 1975; Bergman et al., 1977). Tundra vegetation, density, structure, and composition are dependent on differences in minor topographic relief (Neiland and Hok, 1975; Webber and Walker, 1975; Taylor, 1981), which may be as little as 20 to $30 \mathrm{~cm}$ in the Teshekpuk Lake area. However, some plant communities common in other areas of the coastal plain were not found in the Teshekpuk Lake area except for the extreme southern portion. For example, a dwarf shrub community with Betula nana was found to the east in the Colville River delta, south of Teshekpuk Lake, and to the west along Meade River. However, this community does not occur over most of the Teshekpuk Lake area. The occurrence of this dwarf shrub community is concurrent with Quaternary surficial deposits of marine silts, which are different than the sand and gravel deposits in other areas outside the Teshekpuk Lake area. The absence of the cover type also may be due to relative landform age. The Teshekpuk Lake area has a history of lake coalescence, drainage, and reformation (Brown and Sellmann, 1973; Weller and Derksen, 1979). This area of active change occurs north of the Quaternary surficial deposits boundary and is younger than the 120000 year old Pelukian beach to the south (Reimnitz et al., 1988). The Betula nana dwarf shrub type can be found along the Pelukian beach boundary and south, but not north, of the boundary. The constant landform change lends itself well to pioneer plants dependent on wind- disseminated seed such as Salix spp. This may be the cause for an abundance of Salix spp. in the Teshekpuk Lake area and an absence of Betula spp., which has a much heavier seed not easily transported by wind.

\section{CONCLUSIONS}

The project area is a dynamic region with constantly changing landforms and land cover types. The satellite map proved useful in updating current knowledge of vegetation and landform conditions in the Teshekpuk Lake area. Ocean and lake shorelines and small ponds shown on 1954 U.S. Geological Survey topographic maps were altered or nonexistent on the 1986 satellite map (Markon, 1989). In other areas, lake shorelines that were mud flats in 1979 (J. Helmericks, pers. comm. 1991) were field checked and accurately indicated as moist sedge meadow on the SPOT-derived map.
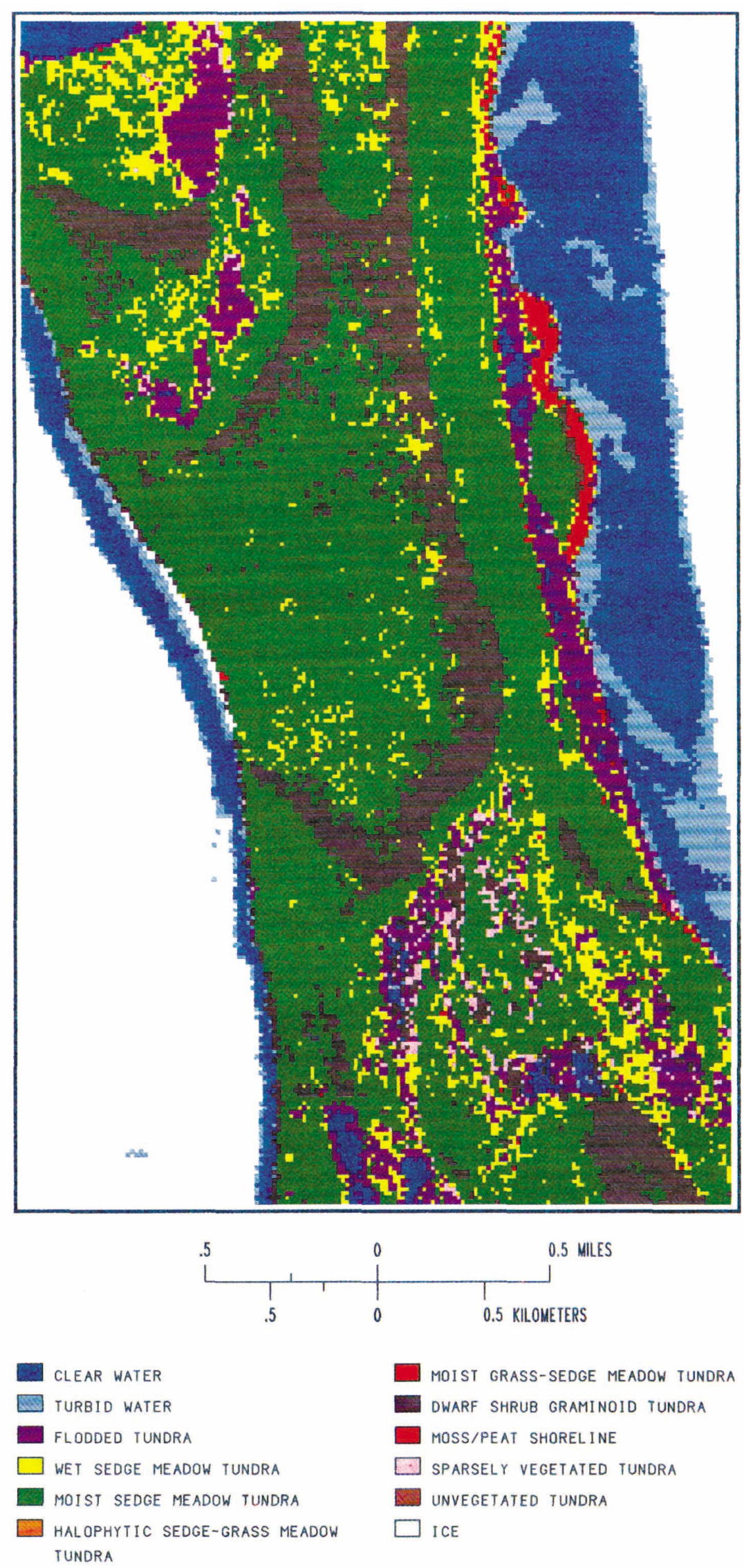

FIG. 7. A 1:30 000 scale SPOT map that distinguishes a low relief lake shoreline with moss/ peat (right) and high relief lake shoreline. Note the presence of ice (white signature) on both basins. 
The digital land cover data may be used to determine waterfowl habitat preferences by combining geographical coordinates of waterfowl sightings with the geo-referenced land cover data (Douglas et al., 1988). The data also may be manipulated to display, quantify, and qualify various habitat types in whole or in part, and in different map projections. The data produced for this project have other uses. The final land cover map and the original MSS data may increase the current knowledge of geomorphic processes in the area. The large synoptic view provided by the SPOT satellite gives the user a unique look at the entire area, which is useful for studies involving current and historical shorelines (Markon, 1989), lake orientation, drainage patterns, and lake coalescence (Weller and Derksen, 1979). The data may also be used to estimate sediment transport over the ice by wind (Reimnitz and Maurer, 1979). Coastal sea ice classified as unvegetated tundra (Fig. 2), is most likely sediment entrained from the shallow seafloor through formation of frazil and anchor ice under turbulent fall-storm conditions (Reimnitz et al., 1992; Reimnitz et al., 1993). Using Pritchard's (1984) free-drift model for the movement of coastal ice, and estimates of sediment load in the discoloured ice of Figure 2, one could calculate sediment-transport rates to the deep Canada Basin. Finally, a geo-referenced data base allows the biologist or manager the flexibility to modify the data to suit individual needs.

\section{ACKNOWLEDGEMENTS}

Financial support for this research was provided by the Bureau of Land Management, Minerals Management Service, and the U. S. Fish and Wildlife Service, Alaska Fish and Wildlife Research Center(AFWRC). Pilot/naturalist Jim Helmericks, Colville Village, safely transported us to and from our remote study sites. We especially thank Karen Bollinger and Mike North, AFWRC, K. C. Jensen, Mark Miller, and Eric Taylor, Texas A \& M University (TAMU) for their assistance in collecting data on plant communities. Barbara Murray, University of Alaska, Fairbanks, identified the mosses. Milton W. Weller, TAMU, provided valuable advice concerning classification of Arctic Coastal Plain vegetation communities. Critiques of our manuscript made by Brian Bogaczyk, Helmut Epp, Jerry Hupp, Stephen R. Johnson, Erk Reimnitz, Stephen Talbot, David Yokel, Paul A. Vohs, Peter Wainwright, Leslie Wakelyn, and Milton W. Weller helped us to improve it.

\section{REFERENCES}

AILTS, B., AKKERMAN, D., QUIRK, B., and STEINWAND, D. 1990. LAS 5.0 - An image processing system for research and production environments. In: American Congress on Surveying and Mapping (ACSM)/American Society for Photogrammetry and Remote Sensing (ASPRS) Annual Convention, Denver, CO., Proceedings, Bethesda, Maryland, ACSM/ASPRS 4:1-12.

ARGUS, G.W. 1973. The genus Salix in Alaska and the Yukon. Ottawa: National Museum of Canada. Publications in Botany, No. 2. 279 p.
BERGMAN, R.D., HOWARD, R.L., ABRAHAM, K.F., and WELLER, M.W. 1977. Water birds and their wetland resources in relation to oil development at Storkersen Point, Alaska. U.S. Fish and Wildlife Service Resource Publication 129. 38 p.

BLACK, R.F., and BARKSDALE, W.L. 1949. Oriented lakes of northern Alaska. Journal of Geology 57(2):105-118.

BROWN, J., and SELLMANN, P.V. 1973. Permafrost and coastal plain history of arctic Alaska. In: Britton, M., ed. Alaskan arctic tundra. Naval Arctic Research Laboratory, Arctic Institute of North America, Technical Paper No. 25:31-47.

CONGALTON, R.G. 1991. A review of assisting the accuracy of classifications of remotely sensed data. Remote Sensing of Environment 37:35-46.

DANA, R.W. 1982. Background reflectance effects in Landsat data. Applied Optics 21:4106-4111.

DERKSEN, D.V., WELLER, M.W., and ELDRIDGE, W.D. 1979. Distributional ecology of geese molting near Teshekpuk Lake, National Petroleum Reserve-Alaska. In: Jarvis, R. L., and Bartonek, J.C., eds. Management and biology of Pacific Flyway geese. Corvallis: Oregon State University Book Stores, Inc. 189-207.

DERKSEN, D.V., ROTHE, T.C., and ELDRIDGE, W.D. 1981. Use of wetland habitats by birds in the National Petroleum ReserveAlaska. U.S. Fish and Wildlife Service Resource Publication 141. $27 \mathrm{p}$.

DERKSEN, D.V., ELDRIDGE, W.D., and WELLER, M.W. 1982. Habitat ecology of Pacific black brant and other geese moulting near Teshekpuk Lake, Alaska. Wildfowl 33:39-57.

DERKSEN, D.V., BOLLINGER, K.S., ESLER, D., JENSEN, K.C., TAYLOR, E.J., MILLER, M.W., and WELLER, M.W. 1992. Effects of aircraft on behavior and ecology of molting black brant near Teshekpuk Lake, Alaska. Anchorage, Alaska: U.S. Fish and Wildlife Service. Final Report. 227 p.

DOUGLAS, D.C., GRESLIN, J.C., and PANK, L.F. 1988. Satellite telemetry and Geographic Information Systems: Powerful tools for wildlife research and management. In: Bunyoff, G.J., ed. International Symposium on Advanced Technology in Natural Resource Management. Fort Collins, Colorado. 83-93.

FERGUSON, R.S. 1991. Detection and classification of muskox habitat on Banks Island, Northwest Territories, Canada, using Landsat Thematic Mapper data. Arctic 44 (Supp. 1):66-74.

FLEMING, M.D. 1988. An integrated approach for automated cover type mapping of large inaccessible areas in Alaska. Photogrammetric Engineering and Remote Sensing 54:357-362.

HAY, A.M. 1979. Sampling designs to test land-use accuracy. Photogrammetric Engineering and Remote Sensing 45:529-533.

HORD, R.M., and BROONER, W. 1976. Land-use map accuracy criteria. Photogrammetric Engineering and Remote Sensing 42: 671-677.

HULTEN, E. 1968. Flora of Alaska and neighboring territories. Stanford, California: Stanford University Press. 1008 p.

KÜCHLER, A.W. 1966. Potential natural vegetation of Alaska. Washington, D. C.: U.S. Geological Survey, National Atlas Series Sheet No. 89. 
LOVELAND, T., MERCHANT, J., OHLEN, D., and BROWN, J. 1991. Development of a land cover characteristics data base for the conterminous U.S. Photogrammetric Engineering and Remote Sensing 57: 1453-1463.

MARKON, C.J. 1989. Detection of coastal shoreline erosion using SPOT MSS data and Arc/Info. Proceedings of IGARSS ' 89 and the 12th Canadian Symposium on Remote Sensing, Vancouver, Canada 3: 1656-1658.

1992. Land cover mapping of the upper Kuskokwim

Resource Management Area, Alaska, using Landsat and a digital data base approach. Canadian Journal of Remote Sensing 18: $62-71$

MORRISSEY, L.A., and ENNIS, R.A. 1981. Vegetation mapping of the National Petroleum Reserve in Alaska using Landsat digital data. U.S. Geological Survey Open-File Report 81 -315. $25 \mathrm{p}$.

MUELLER-DOMBOIS, D., and ELLENBERG, H. 1974. Aims and methods of vegetation ecology. New York, N.Y.: Wiley. 547 p.

NEILAND, B.J., and HOK, J.R. 1975. Vegetation survey of the Prudhoe Bay region. In: Brown, J., ed. Ecological investigations of the Tundra Biome in the Prudhoe Bay region, Alaska. Fairbanks: Biological Papers of the University of Alaska. Special Report No. 2. 73-78.

PEARCE, C.M. 1991. Mapping muskox habitat in the Canadian high Arctic with SPOT satellite data. Arctic 44 (Supp. 1):49-57.

PENFOLD, M.J., and BUOY, L.J. 1986. Combining agency goals to meet wildlife needs and manage oil and gas resources in Alaska. Transactions of the North American Wildlife and Natural Resources Conference. Washington, D.C.: Wildlife Management Institute 51: $98-106$.

PITELKA, F.A. 1974. An avifaunal review for the Barrow Region and North Slope of arctic Alaska. Arctic and Alpine Research 6(2): $161-184$.

PRITCHARD, R.S. 1984. Beaufort Sea ice motions. In: Barnes, P.W., Schell, D.M., and Reimnitz, E., eds. The Alaskan Beaufort Sea. Orlando, Florida: Academic Press. 95-113.

REIMNITZ, E., GRAVES, S.M., and BARNES, P.W. 1988. Beaufort Sea coastal erosion, sediment flux, shoreline evolution, and the erosional shelf profile. U.S. Geological Survey. Miscellaneous Geologic Investigations Series, map I-1182-g. $22 \mathrm{p}$.

REIMNITZ,E., and MAURER, D.K. 1979. Eolian sand deflationa cause for gravel barrier islands in arctic Alaska? Geology 7: $507-510$.

REIMNITZ, E., MARINCOVICH, L., Jr., McCORMICK, M., and BRIGGS, W.M. 1992. Suspension freezing of bottom sediment and biota in the Northwest Passage and implications for Arctic Ocean sedimentation. Canadian Journal of Earth Science 29: $693-703$.

REIMNITZ, E., McCORMICK, M., McDOUGALL, K., and BROUWERS, E. 1993. Sediment export by ice rafting from a coastal polynya, Arctic Alaska, U.S.A. Arctic and Alpine Research 25:83-93.
RIEGER, S., SCHOEPHORSTER, D.B., and FURBUSH, C.E. 1979. Exploratory soil survey for Alaska. Anchorage, Alaska: U.S. Department of Agriculture, Soil Conservation Service. 213 p. + maps.

SELKREGG, L.L. 1975. Alaska regional profiles; southwest region. Anchorage, Alaska: University of Alaska, Arctic Environmental and Information Data Center. 265 p.

SELLMANN, P.V., CAREY, K.L., KEELER, C., and HARTWELL, A.D. 1972. Terrain and coastal conditions on the arctic Alaskan coastal plain. Hanover, N.H.: Corps of Engineers, CRREL, ARPA Order 1615. 72 p.

SPETZMAN, L.A. 1959. Vegetation of the arctic slope of Alaska. Washington, D.C.: U.S. Geological Survey Professional Paper 302-B. 58 p.

STORY, M., and CONGALTON, R.G. 1986. Accuracy assessment: A user's perspective. Photogrammetric Engineering and Remote Sensing 52:835-841.

SWAIN, P.H., and DAVIS, S.M. 1978. Remote sensing: The quantitative approach. New York, N.Y.: McGraw-Hill, Inc. $396 \mathrm{p}$.

TALBOT, S.S., and MARKON, C.J. 1986. Vegetation mapping of Nowitna National Wildlife Refuge, Alaska using Landsat MSS digital data. Photogrammetric Engineering and Remote Sensing 52(6): $791-799$.

TALBOT, S.S., and MARKON, C.J. 1988. Intermediate-scale vegetation mapping of Innoko National Wildlife Refuge, Alaska using Landsat MSS digital data. Photogrammetric Engineering and Remote Sensing 54(3): 377-383.

TAYLOR, R.J. 1981. Shoreline vegetation of the arctic Alaska coast. Arctic 34: 37-42.

VAN GENEREN, J.L., and LOCK, B.F. 1977. Testing land use map accuracy. Photogrammetric Engineering and Remote Sensing 43: 1135-1137.

VIERECK, L.A., and LITTLE, E.L. 1972. Alaska trees and shrubs. U.S. Department of Agriculture. Agriculture Handbook 410. $265 \mathrm{p}$.

VIERECK, L.A., and DYRNESS, C.T. 1980. A preliminary classification system for vegetation of Alaska. U.S. Department of Agriculture, U.S. Forest Service. General Technical Report PNW-106. 38 p.

WAHRHAFTIG, C. 1965. Physiographic divisions of Alaska. Washington, D.C.: U.S. Geological Survey, Professional Paper 482. $52 \mathrm{p}$.

WEBBER, P.J., and WALKER, D.A. 1975. Vegetation and landscape analysis at Prudhoe Bay, Alaska: A vegetation of the Tundra Biome Study Area. In: Brown, J., ed. Ecological Investigations of the Tundra Biome in the Prudhoe Bay region, Alaska. Fairbanks: Biological Papers of the University of Alaska. Special Report No. 2. 81-91.

WELLER, M.W., and DERKSEN, D.V. 1979. The geomorphology of Teshekpuk Lake in relation to coastline configuration of Alaska's coastal plain. Arctic 32:152-160.

WILLIAMS, I.L., YEEND, W.E., CARTER, L.D., and HAMILTON, T.D. 1977. Preliminary surficial deposits map, NPRA. U.S. Geological Survey, Open-File Report 77-868. 